\title{
LA LIBERTAD EN LA CONSTITUCIÓN CHILENA: DIMENSIÓN POLÍTICA, SOCIAL, ECONÓMICA Y CULTURAL
}

\author{
José Luis Cea Egaña \\ Profesor Titular de Derecho Constitucional \\ Pontificia Universidad Católica de Chile y Universidad de Chile

\section{LA LIBERTAD EN LA CONSTITUCION CHILENA}

Sean mis primeras palabras para agradecer la invitación a participar, una vez más, en esta que para mí es ya mi casa, en un ciclo dedicado a un tema de tanta importancia como es el de la libertad en cuanto derecho esencial de la persona humana.

Deseo también, en estas palabras introductorias, manifestar un especial reconocimiento a la Profesora Luz María Reyes Santelices porque junto con distinguirme al invitarme, me da la oportunidad de manifestarle, con entera franqueza ante Uds., el reconocimiento que hago de ella, por la notable labor que lleva a cabo en la Escuela de Derecho de esta Universidad.

Es un honor también participar en este ciclo junto a los Profesores Juan de Dios Vial Larraín y Gonzalo Rojas Sánchez, queridos amigos, que abordarán temas que complementan el que voy a exponer esta tarde.

Y es también, por último, una ocasión para mí emocionante estar ante Uds. cuando La Serena celebra sus 455 años de existencia, y la Corte de Apelaciones de esta ciudad, de la cual mi bisabuelo fue Ministro hace muchos años, también conmemora 150 años de fructífera contribución al desarrollo del Derecho en esta región y en el país.

\section{LA LIBERTAD, DERECHO ESENCIAL}

Se ha anunciado por nuestro expositor que el tema que abordaré es el de "La Libertad en la Constitución Chilena". Quiero darle el carácter, como ha ocurrido en años anteriores, de una conversación. Tendremos después la oportunidad de analizar los juicios y comentarios que vamos a ir exponiendo ante Uds., y darles, por lo tanto, la estructura, algo más formal, de una conferencia para su publicación.

Quiero, entonces, que dialoguemos sobre la libertad en la Constitución chilena vigente. $Y$ lo haremos partiendo del supuesto que la libertad es, como lo dice el título de este ciclo, un derecho esencial.

Algunos constitucionalistas, v.gr., Pereira Menaut, la doctrina más moderna podríamos decir, especialmente en Europa, sostiene que la libertad junto a la igualdad son presupuestos de los derechos fundamentales. Vale decir, son epistemológicamente 
anteriores a los derechos fundamentales, y todavía más, se dice que la libertad y la igualdad representan los valores constitutivos más relevantes de ese concepto, que con tanto acierto acaba de mencionar la Profesora Reyes Santelices, que es el querido, capital pero poco examinado concepto de la dignidad de la persona humana.

Creo, sin embargo, que la libertad concebida en esos términos, como un presupuesto de los derechos fundamentales y, tal vez, como el derecho más esencial de todos los que arrancan de la dignidad de la persona humana, debe entenderse por Uds., y aquí advierto y les agradezco la presencia de muchos alumnos, como un valor, como un concepto matriz y decisivo, que a pesar de ser tan relevante, tan importante, jamás se puede comprender y practicar con el carácter de un valor de alcance ilimitado, absoluto.

La libertad, queridos alumnos, debe por lo tanto conjugarse, armonizarse o ser conciliada siempre con el orden, por eso, creo firmemente que no hay libertad en el desorden, y que uno de los puntos más difíciles para nosotros, pueblos jóvenes, es lograr justamente vivir en libertad, pero conservando el orden, porque la libertad como la igualdad son conceptos instrumentales y nunca pueden refutarse valores o ideas, por relevantes que sean, autojustificados o con legitimación en sí mismos.

Debido a esa exigencia, vale decir, a la necesidad de justificar, de legitimar racionalmente el ejercicio de la libertad, concluyo planteando una primera observación: La libertad requiere siempre del Derecho y, dentro del Derecho, Uds, son Profesores o alumnos que lo estudian, se reconoce que la Constitución es la Ley Suprema, la manifestación máxima del ordenamiento jurídico positivo y justo de un Estado de Derecho. La Constitución, en otras palabras, presupone y exige la libertad, pero la libertad reclama también la vigencia efectiva del orden propugnado en la Constitución para ser bien ejercida.

La libertad disfrutada dentro de la Constitución, o ejercida conforme a la Constitución, se legitima, así como también creo que una Constitución que no garantiza, efectivamente, el ejercicio de la libertad, nunca es ni puede ser legítima. Uno y otro concepto, por lo tanto, son recíprocamente indispensables.

\section{II. ¿QUÉ ES LA LIBERTAD?}

Comienzo con una referencia a los conceptos de libertad y de Constitución.

Con sujeción al plan, ya explicado, de mis dos exposiciones en la tarde, no voy a profundizar, por cierto, en las complejas profundidades que tiene el concepto de libertad. Entiendo que el Profesor Vial tuvo ya la oportunidad de hacerlo con brillo en este mismo ciclo de conferencias. Pero, sí estimo indispensable decir algunas palabras acerca de lo que yo entiendo por libertad y por Constitución, teniendo presente que son dos conceptos fundamentales en el desarrollo de mis charlas. Más aún, creo que es necesario, sobre todo pensando en Uds., queridos alumnos y alumnas, transmitirles cual es la visión que tengo de la libertad y de la Constitución, porque me asiste la convicción, que 
en Chile, particularmente en punto a la Constitución existen confusiones, muchos equívocos $y$ a veces errores.

Se pide, por ejemplo, o se espera de las Constituciones y de las reformas constitucionales, frutos o efectos que es imposible que den los libros, si acaso antes la semilla que rinde esos frutos no está sembrada en el espíritu o en el alma, en el corazón de los chilenos y chilenas.

¿Qué es lo que intento yo describir con la idea de libertad?, ¿cuál es el concepto que tengo de libertades y que desarrollaré, brevemente, en estas exposiciones?

Percibo la libertad como una capacidad esencialmente humana, inherente a la persona, consistente en la facultad de obrar o no, de decidir, responsablemente, según la conciencia de cada sujeto. La concibo, entonces, como un atributo del ser humano, típico de él, consistente en la posibilidad de decidir o de obrar según la conciencia de cada sujeto en su sano juicio. Queda, por lo tanto, involucrado dentro del concepto de libertad, la idea de voluntad, y también de responsabilidad, que le es inherente.

Esa capacidad para lograr finalidades racionalmente descubiertas y anheladas, me parece que es, necesariamente, una aptitud para obrar en términos de un juicio que tiene que ser de legitimidad en punto a lo que se hace o no se hace.

Por eso, precisamente, porque el ejercicio de la libertad se justifica o se legitima según sea la conducta lícita o ilícita, legítima o ilegítima, justa o injusta, correcta o incorrecta, proporcionada o no al fin perseguido que el sujeto realiza libremente, resulta que podemos decir que hay casos en que uno puede obrar con libertad, pero que lo hace indebida, torcida o injustamente. En esos casos, podríamos agregar que se incurre en abuso de la libertad, o que también se puede incurrir en delitos a propósito del ejercicio de la ella, como ocurre, por ejemplo, en el ámbito de la libertad de expresión.

Debo poner de relieve, consecuente con lo recién expuesto, que la libertad es susceptible de ser abusada; que pueda ser ejercida delictualmente y que, consiguientemente, la libertad no es un bien jurídico ni un bien moral de contornos indefinidos o de contenido cuyo ejercicio faculte al titular para obrar con rasgo ilimitado.

La libertad tiene, entonces, queridos alumnos y amigos, que hallarse delimitada, regulada, acotada en su disfrute, por el Derecho objetivo que tendríamos que llamar justo. No cualquier ordenamiento jurídico se puede aceptar como el encuadrante o delimitante de la libertad. Repito: la libertad sólo puede ser regulada a través de un ordenamiento jurídico justo. Pero si esa libertad es delimitada a través de tal especie de ordenamiento jurídico, síguese que el ejercicio de la libertad se vuelve legítimo. Por ende, el ejercicio de la libertad fuera de los contornos o de los límites del Derecho justo es libertinaje. Eso, por desgracia, también existe en nuestra sociedad.

Obrar libremente pero sin respeto de los límites legítimemente previstos es incurrir en desorden y terminar en anarquía. 


\section{III. ¿QUÉ ES LA CONSTITUCIÓN PARA LA LIBERTAD?}

En la Constitución encontramos la primera y máxima normativa del Derecho positivo que cumple el objetivo de regular, delimitar o acotar el ejercicio de la libertad para que se vuelva legítima. Por cierto, y lo vuelvo repetir, mi premisa vale bajo condición que la Constitución misma, la propia Carta Fundamental haya sido legítimamente establecida, desarrollada y aplicada, y que respete, por lo tanto, dentro de sus límites justos, lo que es el ejercicio de la libertad.

Pues bien, debo puntualizar que la libertad es una sola, pero se proyecta o manifiesta, se exterioriza, podríamos decir, en múltiples facetas o aspectos de nuestra convivencia. No hay momento alguno de nuestra convivencia, cualquiera sea la edad o situación del sujeto que razona, en el que pueda imaginarse siquiera que la libertad terminó o que, ante su falta, ella no es anhelada.

Empero, aquí y esta tarde, conversaremos tan sólo de cuatro de esos aspectos, probablemente los más importantes, pero que no agotan el universo tan rico y variado, de la libertad. Así lo reconoce, en esa cosmovisión tan amplia, el Art. 10 inciso primero de nuestro Código Político, cuando dice que los hombres y las mujeres nacen libres e iguales en dignidad y en derechos, o que la persona, como se dice ahora en virtud de la reforma constitucional última, nace libre e igual en dignidad y derechos.

¿Qué podemos decir a propósito de la Constitución? ¿cuáles son sus ligámenes con la libertad?

La Constitución es, podríamos decir siguiendo las enseñanzas del gran jurista alemán Herman Heller, la normalidad de la vida normada por el Derecho positivo. Voy a repetir lo que para mí es una definición breve, pero sustanciosa: Una Constitución es la normalidad de la vida, de la convivencia humana, normada por el Derecho positivo. Esa definición, de Herman Heller en su "Teoría del Estado", publicada originalmente en 1934, encierra una verdad de importancia y que creo pertinente explicar.

En efecto, una Constitución, y que importante sería que en Chile lo comprendiéramos así queridos alumnos, no es más ni debe ser más que la normalidad de la convivencia de los chilenos normada por un Código Político supremo. Esa normalidad de la vida transcurre, ya hemos dicho, bajo el concepto de libertad o asociada con el concepto de igualdad dentro del orden. Libertad e igualdad de la persona, disfrutadas dentro del orden, hacen la normalidad de la convivencia y permiten que ella sea normada por un Código Político y su legislación complementaria.

La Constitución, consecuentemente, podríamos decir que es, y en Chile pienso que así ocurre o debe ser, es el Estatuto de la Libertad. Por eso que tiene razón Luz María Reyes cuando invita a tratar este tema porque existe un nexo, un ligamen sustancial e íntimo, inescindible, inseparable, entre la Constitución y la libertad. La Constitución, y esto lo reconoce toda la doctrina del mundo que se ha ocupado del tema, es y tiene que ser siempre el estatuto de la libertad de la persona en la Sociedad civilizada. 


\section{LIBERTAD, CONSTITUCIÓN Y GOBIERNO}

Para eso se establece, organiza y controla, lo que es el segundo objetivo de una Constitución, quiero decir, el Instrumento de Gobierno, Parte Orgánica del Código Político. Este es, entonces, un instrumento, un mecanismo o dispositivo, que tiene el carácter de tributario o subordinado de aquel Estatuto de la Libertad cuya realización es el objetivo básico y último de la Constitución como institución del Estado Democrático.

Lo que acabo de manifestar es importante, porque va a tener consecuencias en el desarrollo del argumento que les expondré. Pues si lo más importante del telos de la Constitución es asegurar la libertad dentro del orden, vale decir con justicia, también tenemos que reconocer entonces que ese Estatuto de la Libertad es lo más relevante y que el Instrumento de Gobierno, el sistema político, el funcionamiento real de los órganos del Estado de Derecho, tiene que siempre entenderse, interpretarse y aplicarse como coayudante, instrumental o al servicio del Estatuto de la Libertad ya realzado. Lo digo, lo enfatizo, lo subrayo, porque no puedo callar que en otros países, incluso algunos hermanos, sus pueblos se hallan convulsionados en la vida política e institucional, como la República de Venezuela. Queda, a raíz de ese análisis, la impresión que se invierten los términos, de modo que el Estatuto de la Libertad queda subordinado a una reorganización de las instituciones políticas o Instrumento de Gobierno, sin que se asegure el desenlace democrático.

Si reconocemos que la Constitución es y debe ser el Estatuto de la Libertad, como así mismo, ella debe ser preponderante sobre el Instrumento de Gobierno, desprendo al menos dos consecuencias que les pido recordar.

En primer lugar, que no puede haber ni existir, como tampoco aceptar, el viejo aforismo de la Razón de Estado para atropellar la libertad que se ejerce dentro de la justicia y con sujeción al Derecho. Repito, no se puede aceptar la Razón de Estado con finalidades de seguridad, eficiencia en el desempeño de los órganos estatales, etc. cuando ello es con menoscabo o atropello de la libertad que los ciudadanos o los grupos ejercen dentro de la Constitución y las leyes legítimamente establecidas y aplicadas. Y una segunda consecuencia, consiste en que toda duda o vacilación, cualquier problema o dilema que surja en la aplicación de esta primera norma, o sea, que no hay Razón de Estado que valga o justifique para atropellar la libertad dentro del orden, consiste en que, el Juez, el Ministro de Corte, el Profesor que enseña, el Abogado que litiga, la autoridad regional, todo miembro de nuestra comunidad cívica, debe resolverla siempre en favor de la libertad y nunca en pro del Poder.

Al fin y al cabo, lo recién conversado no es más que realzar el Ethos o el sentido final y sustantivo que justifica el Constitucionalismo como proceso humanista y humanizador del concepto y ejercicio de la Soberanía.

El Constitucionalismo, queridos alumnos y amigos, no es más que eso: Un proceso de civilización creciente que va infundiendo un sentido humanista a la convivencia, sobre la base de hacer del Poder o Soberanía, un instrumento limitado, pues tiene que 
estar siempre al servicio de la libertad, de la igualdad, y en definitiva, de la dignidad de la persona humana y de sus derechos fundamentales. Coherente con ese postulado esencial, fluye también que el Constitucionalismo propugna la aplicación de acciones y recursos judiciales para la protección de aquellos atributos del ser humano.

\section{LIBERTAD POLÍTICA}

Con esas ideas en mente, entremos ahora, de manera más concreta a examinar el primero de los cuatro aspectos que nos hemos propuesto exponer sobre la libertad en nuestra Constitución. Me refiero al punto de vista de la Libertad Política o en sentido político, y que da lugar a lo que, en 1976, en las Jornadas de Derecho Público que se realizaron en la Universidad Católica de Chile, se denominó la Constitución Política.

La libertad en su acepción política engendra, configura y determina el significado de la Constitución Política y esta última a su vez, es la que regula aquella especie de libertad política. Lo mismo, podríamos decir, va a suceder con los otros tres aspectos, esto es, con la Constitución Social, por ende la Constitución Económica y la Constitución Cultural.

En este campo, por ende, de la libertad política y de su Constitución homónima, decimos que la libertad es posible sólo en democracia, entendida no sola ni simplemente como una Forma de Gobierno, sino que con la riqueza y exigencias sustantivas de un modo o estilo de vida, caracterizado por el respeto recíproco, la tolerancia y el diálogo; por el cumplimiento de los deberes; por un alto sentido de la responsabilidad, del esfuerzo, del sacrificio y del trabajo; por el acatamiento de la legalidad; por la convivencia con transparencia, solidaridad y participación.

Esa serie o cúmulo de valores, sólo es posible vivirlos y transmitirlo a los jóvenes en una democracia y dentro del Derecho, ese ambiente se denomina Democracia Constitucional y el Estado de Derecho.

Por eso la libertad existe en nuestra Constitución, se contempla en ella a propósito del origen de la Soberanía, de la residencia del Poder, del ejercicio de aquella potestad suprema, como asimismo del control y responsabilidad que cabe hacer efectivo respecto de quienes desempeñan el mando supremo del Estado.

Esta primera aproximación a la libertad política, vale decir, que esa especie de libertad la tenemos y podemos ejercitar a propósito de la generación, ejercicio, control y responsabilidad del Poder, la concretamos en las elecciones, libres, periódicas, informadas, conforme a lo previsto en los Arts. $13^{\circ}$ y siguientes del Código Político. La manifestamos también al mantener, como a muchos chilenos nos agrada hacerlo, una visión o actitud independiente frente a los procesos políticos, o bien, como muchos chilenos también lo hacen y es absolutamente legítimo que así suceda, militando en partidos políticos. 
Tal vez, lo que no resulta desde ningún punto aceptable, por lo tanto, es la apatía, la indiferencia o indolencia, la comodidad o la displicencia frente a aquellos fenómenos políticos.

Los partidos políticos o la independencia frente a ellos son, entonces, opciones que tenemos para ejercer nuestra libertad política dentro de la Constitución.

La manifestamos esta libertad política, a mayor abundamiento, a través de la libertad de expresión, sobre todo cuando ella, a través de la libertad de emitir opinión e informar, se hace efectiva mediante los medios de comunicación social.

Pero en la Constitución de Chile hoy, y el que sigue es un juicio que manifiesto con clara advertencia que es una posición individual ante el asunto que estoy exponiendo, que el régimen de la libertad se halla correctamente articulado, pero que es insuficiente. Creo, en otras palabras, que el concepto de la libertad política como se entiende hoy o tendría que ser concebido, en Chile aparece jibarizado, reducido o menoscabado. Tenemos, para comprobar lo que digo, asegurados nada más que los derechos llamados de la primera generación, vale decir los consistentes en concurrir, periódicamente, a elegir autoridades por períodos que son más o menos prolongados: 6 años en el caso del Jefe de Estado, 4 años en los Diputados, 8 años en los Senadores, 4 años también tratándose de los Concejales en los Municipios. No tenemos otras oportunidades de ejercer la libertad política con sus proyecciones en el control y en el ejercicio de la responsabilidad de nuestros mandatarios. Faltan, consecuentemente, los que se denominan derechos de la segunda generación.

Yo sé que esta es una cuestión candente, es un problema pendiente y de remota solución en Chile. La segunda generación de derechos en materia de libertad política, recordémoslo, dice relación con el ejercicio de la democracia semi directa o semi representativa, mediante o a través del plebiscito y el referendo, la iniciativa popular, la revocación de mandatos y sentencias, y en general, lo que los alemanes hoy en su doctrina denominan la Democracia Directiva; o lo que G. Burdean, hace ya cincuenta años. aproximadamente, calificó como la Democracia Gobernante y no solamente como democracia gobernada.

Creo que en Chile nos encontramos en esa situación: Somos una Democracia Gobernada, pues no tenemos las oportunidades, incentivos y medios para transitar descle esa situación a lo que es la democracia del futuro, vale decir, la Democracia Gobernante, participativa o directiva, como les he dicho. Me parece, además, que esa falta o insuficiencia de libertad política dentro del orden se extiende a otro fenómeno que seguramente llega cerca de Uds, y que ya tal vez, en alguna oportunidad, yo, en este mismo hermoso salón, les he expuesto. Me refiero a la preocupación que siento por la falta de una efectiva Descentralización del Poder Político en Chile. Es el interesantísimo tema de la regionalización integralmente concebida y no sólo de la descentralización administrativa o de la desconcentración de los servicios públicos que integran la Administración del Estado. Ese es un campo de reformas y de participación política que me parece, a la altura de la democracia que tenemos, que con los tiempos que han 
transcurrido, con la larga experiencia que se ha recogido, ya tendría que estar siendo, poco a poco, paulatinamente reconocida y regulada en nuestra Carta Fundamental.

En otras palabras, falta descentralización del Poder político para que exista, coetáneamente, una mayor libertad política de los chilenos.

En ese sentido, me parece que debemos abrir lo que aparece hoy manifestado en el Art. 5을 inciso primero, de nuestra Carta Fundamental, a esa democracia directiva, participativa, solidaria y descentralizada, en que como lo voy a decir con mayor detalle, la libertad se ejerza en aspectos de la convivencia que hoy aparecen menoscabados, especialmente en el ámbito de la Sociedad Civil, en el ámbito de la economía, de la cultura, de la ciencia y la tecnología.

Tenemos que infundir mayor sustancia o densidad conceptual, a esa frase perdida a la cual los profesores no le damos la importancia que merece y que aparece en el Art. $19^{\circ}^{\circ} 15$, inciso sexto, cuando dice que, la Constitución asegura el pluralismo político. Esa frase tiene una enorme trascendencia. Considero que tendría que ser una base institucional de Chile. Lamentablemente, por razones históricas que podría exponer, pero que no viene al caso hacerlo, esa frase quedó perdida, olvidada, dentro de una línea, en un inciso de un largo y programático precepto constitucional, en circunstancia que si Uds, captan la riqueza que encierra, tendría que llevarnos a reconocer que es de singular relevancia: "La Constitución asegura a todas las personas el pluralismo político", eso es libertad política dentro de la Constitución y las leyes dictadas en sujeción a ellas.

\section{LIBERTAD SOCIAL}

Quisiera rápidamente, en los minutos que me faltan de esta primera charla, entrar en la segunda dimensión, aspecto o ámbito en que se manifiesta la libertad en la Constitución. Me refiero a la proyección de la libertad en la sociedad, lo que podríamos llamar la Constitución Social de Chile y la libertad de la Sociedad según la Constitución chilena.

Proyecto abordar el tema entregándoles, preliminarmente, algunas reflexiones y experiencias en el tópico.

Efectivamente, creo que uno de los cambios más importantes que se están viviendo en el mundo contemporáneo, y por lo tanto, no estoy pensando sólo en Chile, es el que se denomina expansión de la Sociedad Civil, o sea el crecimiento de la gama y funciones de los grupos que forman la Sociedad Civil, correlativo al aumento de la autonomía de la Sociedad Civil de cara o de frente al Estado, especialmente concebido ese en cuanto instrumento de gobierno de la sociedad política o Sociedad Nacional.

He tenido la fortuna de participar, en los últimos dos o tres años, en congresos mundiales o internacionales de Derecho Constitucional y de Ciencia Política. Puedo decirles a raíz de eso, que este tema, el crecimiento de la Sociedad Civil, la expansión de sus roles y autonomía, correlativa a la contracción del Estado-Gobierno, es visuali- 
zado como uno de los temas más complejos, más promisorios para la democracia, y que se vincula con la globalización.

La globalización lleva consigo, en efecto, un replanteamiento profundo de lo que es el Estado, en doble sentido como Nación y en cuanto Gobierno, pero al mismo tiempo todos los estudiosos del asunto subrayan que una de las formas prácticas de superar las consecuencias que pueden ser nocivas y perjudiciales de esa erosión del concepto dual del Estado, se pueden reemplazar y con beneficio mediante una creciente intervención de la Sociedad Civil en lo que es la gestión o manejo de numerosos asuntos, hasta la fecha efectuados por el Estado-Gobierno. La globalización, en otras palabras, no tiene sobre la Sociedad Civil el mismo impacto negativo que tiene o pueda desencadenar sobre el Estado-Gobierno.

Esta nota introductoria tendría que sensibilizarnos respecto de la importancia que encierra plantearse el tema de la libertad en la sociedad, pues equivale a preocuparse de un asunto con una dinámica de expansión o de crecimiento, del no Estado de cara al Estado-Gobierno, el cual se va contrayendo. Algunos ya se plantean, incluso más, la pregunta ¿qué sucederá con la doble dimensión ya aludida del Estado? No digamos a corto plazo pero si a mediano plazo o a largo plazo, ¿desaparecerá? ¿entraremos en un proceso político-social incierto, a raíz de la globalización y otros fenómenos contemporáneos? ¿será ese un proceso de reemplazo del Estado por una nueva forma política?, ¿cuál sería esa nueva forma política? ¿qué secuelas tendría en el Derecho? Esas dudas y otras análogas no afectan a la Sociedad Civil, pues, parece que el futuro estuviera más despejado para ella que para el Estado, entendido tanto como Gobierno, cuanto en identidad de Estado-Nación.

En tal sentido cabría, reconocer que la Constitución chilena tuvo en sus redactores gente bastante visionaria y pionera. Así como en algunos aspectos es perfectamente legítimo criticar la Constitución actual, a mi juicio, en la Parte Orgánica no me parece que sea justo ni razonable criticar nuestra Carta Fundamental en lo que son sus bases institucionales.

Repito que creo que en materias como la visión que el Constituyente tuvo de la libertad en la Sociedad, o lo que llamo la Constitución Social de Chile, los autores de la Carta Fundamental en vigor tuvieron mucha visión y buen criterio.

Si Uds. analizan la que es la norma capital en el tema, o sea el Art. $1^{\circ}$ inciso tercero de la Constitución, desprenderán que allí, cuando se declara de que el Estado reconoce y ampara a los grupos intermedios y les asegura el adecuado margen de autonomía para el cumplimiento de sus fines específicos, hubo bastante acierto en los redactores, ya que hoy tal es la línea de pensamiento que se considera correcta en las más avanzadas reuniones o debates científicos del Constitucionalismo y la Ciencia Política contemporánea.

La idea es que debemos continuar avanzando, cuando tratamos el tema de la libertad en la Sociedad según la Constitución. Tal idea se materializa en el Art. $1^{\circ}$, pero 
ahora en su inciso quinto, esto es, la segunda de las normas que considero fundamentales en este breve enunciado.

Recuerden Uds, que en esa disposición se asegura el derecho de todas las personas a participar con igualdad de oportunidades, pero no con igualdad de resultados, en la vida nacional. Eso es libertad social: el derecho de todos los chilenos a participar con igualdad de oportunidades en la vida nacional.

La libertad en la sociedad se traduce, por lo tanto, en una prioridad de los grupos y familias, de las personas sobre el Estado-Gobierno en la actividad que diga relación con la convivencia en Chile. Hay cierta prioridad de esos actores sobre el EstadoGobierno y eso es importante para la libertad. Renace así el antiguo pero siempre lozano Principio de Subsidariedad.

Nuestro planteamiento asume que el Estado no se confunde con la Sociedad Civil. Puede resultarles elemental tal afirmación, pero iqué importante es captar, con certeza, el significado de estas nociones!

El Estado-Gobierno no se confunde con la Sociedad Civil. Por eso he dicho que la Sociedad Civil ha ganado en autonomía, en identidad propia, en capacidad de acción sin interferencias estatales en espacios o roles de actividad libre. Aquella sociedad, inconfundible con el Estado debe conservar sus áreas de manifestación propias. He sido más de alguna vez crítico respecto de lo que se dice en el Art. № 23 de la Constitución, aquel con el cual se cierra el capítulo tercero. Pero aquí debo, francamente, reconocer que me quedo pensando si equivoqué en los juicios, en que divisaba el surgimiento de los corporativismos estatistas.

Cuando enfoco el tema en la dimensión que estoy procurando transmitirles, descubro, como ya lo realcé, el mérito de los Constituyentes en la concepción y redacción del Art. $1^{\circ}$ incisos primero, tercero y quinto. También descubro su mérito al visualizar como áreas, si bien integradas, distintas de nuestra vida, la actividad social en parangón con el campo de la libertad en el campo político. Eso es lo que Uds. recordarán aparece en el Art. 23, donde se establece, por ejemplo, que los dirigentes de los partidos políticos no podrán ser a su vez dirigentes de gremios, sindicatos, corporaciones, u organizaciones de carácter social. Es cierto que separar uno y otro aspecto de nuestra convivencia es muy difícil, porque como dije la libertad es una sola. Empero, ayuda al Derecho y a los redactores de la norma jurídica y sus intérpretes comprender y compartir, que no son lo mismo, que son conceptos integrados, pero que no pueden ser confundidos.

Desprendo otra conclusión, con lo cual quisiera ir cerrando esta sesión.

Creo, queridos amigos, al hilo de lo que ya expuse a propósito de la importancia que ha adquirido la Sociedad Civil y que va a tener mucho más relevancia aún en los próximos años, que se requiere, especialmente del legislador y de la jurisprudencia, practicar o efectuar los cambios de mayor envergadura en nuestro sistema institucional, cambios que diviso posibles sobre la base de respetar el siguiente postulado: Asu- 
mir que la Sociedad Civil y no el Estado-Gobierno tiene el derecho a gestionar numerosos servicios públicos, sin exclusiones recíprocas, como si se tratara de monopolizar la gestión de áreas de bien común, cuya satisfacción a todos nos atañe.

Voy a repetirlo porque lo creo de gran importancia singular: la Sociedad Civil y no sólo el Estado-Gobierno, tiene el derecho a gestionar numerosos servicios públicos. Pero esta gestión, este desempeño de la Sociedad Civil a través de grupos, organizaciones, gremios, sindicatos, a realizar su contribución al bien común mediante la gestión de servicios públicos, no debe entenderse que se realiza por la Sociedad Civil en virtud de actos de derecho administrativo o decisiones de derecho público, tales como la concesión de servicios públicos, o el permiso de uso sobre bienes nacionales de uso públi$\cos$, o mediante autorizaciones para la construcción de obras públicas.

Tal vez, para algunos de Uds., esto resulte una cuestión compleja, pero para mí es decisivo enfrentarla, sobre todo si hay aquí presente aquí un Profesor de Derecho Administrativo. Porque cuando se hable en Chile de la posibilidad de reconocer a la Sociedad Civil la oportunidad de participar, de intervenir directamente en la gestación y gestión del bien común, como le corresponde al Estado subsidiario, entonces se piensa que esto se hace por las vías de las privatizaciones, vale decir, la enajenación de bienes - actividades empresariales del Estado que pasan al dominio de los particulares para que se manejen con sujeción al Derecho privado, o bien mediante un acto gracioso y unilateral, de magnanimidad o condescendencia que la autoridad estatal manifiesta a través de una concesión de servicios públicos, o a través de un permiso de obra pública o mediante la autorización que ella dispensa para el uso preferente de un bien nacional de uso público.

Pero el Estado sigue siendo el dueño, continúa siendo el responsable, no cesa, en definitiva, de afirmar que es él quien tiene el poder de decisión. Esta es la situación en las tres figuras jurídicas nacionales. Yo creo que, confundir la expansión social con eso es un gran error. Eso es pensar en chico, cuando se torna imperativo hacerlo con grandes ideas.

Si uno quiere, realmente, gozar de libertad social y participar en la sociedad que queremos, por ejemplo, en esta misma región y ciudad, creo que hay numerosos servicios públicos que tendrían que ser gestionados en primera persona por la Sociedad Civil. Me refiero, por ejemplo, al campo de la salud y de la salubridad; de la enseñanza; de la vivienda y la urbanización; del trabajo, de la construcción y administración de las obras públicas. Me refiero también al campo de la seguridad social. Incluso, podríamos comenzar a reflexionar sobre el tema de la seguridad pública y no sólo de la seguridad previsional. Hay algunos atisbos, algunas insinuaciones primarias o elementales en este campo. Diría que el Poder Constituyente en 1980 vislumbró esto, pero se quedó, se rezagó, temió ir más allá de lo que es el pesado y tradicional concepto de EstadoGobierno, en Chile y, entonces, dejó tan sólo como bosquejadas, por ejemplo en el Art. $19^{\circ} \mathrm{N}^{\circ} 19$, a propósito de las acciones de protección de la salud, o en el Art. $19^{\circ}$ № 16 ,con relación al principio de libertad de trabajo, de libertad de afiliación y desafiliación de cualquier actividad o trabajo, o en fin, en el Art. 19 № 19 , tratándose del dere- 
cho a la seguridad social, lo que es este ámbito, a mi juicio mucho más interesante o novedoso, que es el derecho de la sociedad a gestionar, en primera persona, servicios que no tienen por qué ser sólo gestionados por el Estado-Gobierno, directamente o sea por sí mismo, o bien en virtud de los tres tipos de actos administrativos que mencioné, es decir, concesiones, autorizaciones o permisos, todos discrecionalmente emanados de la autoridad y cuyo centro también se reserva.

Creo que con el mismo nombre o con otro que vaya emergiendo, el EstadoGobierno va seguir existiendo, y es bueno, es necesario, es conveniente que sea así.

Siempre entonces, insisto, será necesario reconocer competencias al EstadoGobierno para regular, mediante la ley, el desempeño por grupos o instituciones de la Sociedad Civil, esas actividades de bien común que he mencionado.

Nadie está planteando ni yo, en consecuencia, que en la salud, en el trabajo, en las obras públicas o en la seguridad social, en la seguridad pública o en otros campos que ya mencioné, la Sociedad Civil, a través de sus grupos, organizaciones, etc. se desenvuelva en una situación de completa libertad. Desde luego Uds. recordarán que yo comencé diciendo que esa libertad absoluta no existe, que entenderla así es caer en la anarquía y terminaría con la Libertad. Esta es una facultad que se ejerce racionalmente, es decir, dentro del orden y ese orden, como lo he dicho esta tarde, está en primer lugar declarada en la Constitución y regulada por las leyes. Siempre será necesario, entonces, que el Estado-Gobierno interrumpa, mediante ley, y no de otra manera, en el desempeño por la Sociedad Civil de esas actividades. Pero insisto que el cambio consiste ahora en reconocer que el Estado-Gobierno es el único llamado a gestionar los servicios públicos, como asimismo, que la Sociedad Civil tiene el derecho a fiscalizar, diaria y eficazmente, de manera directa, el desempeño de la administración pública en aquellos rubros.

En otros países, lo voy a decir especialmente con referencia a las democracias escandinavas, este cambio se operó 40 años atrás, y lo que se llama la modernización del Estado, de la cual tanto se habla en Chile, tan poco se entiende y tan escasamente se materializa, consiste fundamentalmente en esto: La liberalización del EstadoGobierno de numerosas actividades de bien común, que asume la Sociedad Civil en primera persona, dentro de los parámetros que la constitución y la ley señala y con las responsabilidades consecuentes. Este proceso, hoy indiscutible en su aporte a la realidad de la democracia y a la legitimidad de los gobiernos, se llama en la cultura anglosajona, la devolución a la Sociedad Civil por Estado-Gobierno de actividades públicas que nada justifica que las siga desarrollando.

Sin embargo, surge aquí un punto que me parece decisivo y, tal vez, tanto o más difícil de llevar a la práctica, que los recién comentados.

Así como reconozco que la Sociedad Civil tiene que asumir diversas actividades de bien común que, en este momento, todavía sigue desempeñando el Estado; así como reconozco que el Estado-Gobierno tiene el derecho a regular por ley, y sólo por ley, el ejercicio de esas actividades por la Sociedad, así también agrego lo que me parece que 
es el tercer elemento clave de esta fórmula. Hay que pensar, en efecto, que la libertad social dentro de la Constitución presume que la Sociedad esté dotada de medios suficientes; que los grupos y que las organizaciones sociales estén facultadas para ejercer acciones y deducir recursos, con los cuales obligar a que el Estado-Gobierno no se exceda de sus competencias en cuanto a la regulación que efectúe de las actividades propias de la libertad social. Este punto, vale decir, que se establezca y rija un estatuto, por virtud del cual la Sociedad o los entes que la integran cuenten con recursos, sobre todo ante los Tribunales de Justicia, mediante los cuales desafiar al Estado-Gobierno cuando este atropella o vulnera los derechos o la gestión de bienes públicos por la Sociedad, me parece que es difícil de lograr en Chile, al menos en el corto plazo. Debemos, sin embargo, crear conciencia en el asunto y preparar el cambio descrito.

Tal vez, lo más problemático de todo lo que he planteado hasta aquí, para concluir esta primera parte, es el asunto que también he planteado. Porque en Chile seguimos teniendo un concepto que me parece que es bastante opuesto al de la libertad política y al de la libertad en la sociedad. Me refiero a que los chilenos pensamos, conscientemente o no, honesta o interesadamente, pero de manera bastante generalizada, por cierto siempre hay excepciones, que el Estado es infalible, Que el Estado-Gobierno no se equivoca, pero que en cambio la Sociedad Civil puede incurrir en abusos, en atropellos, en egoísmos, derroches o excesos, y que el único capaz de enderezarla o encauzarla es la Sociedad Política a través del Estado-Gobierno.

\section{LA LIBERTAD ECONÓMICA Y CULTURAL DE NUESTRA CONSTITUCIÓN}

\section{INTRODUCCIÓN}

Vamos a continuar, con la esperanza que no les resulte tedioso, refiriéndonos a los últimos tópicos que les anuncié como parte de la segunda y última de estas conferencias.

Me referiré, en consecuencia, primeramente a la proyección de la libertad en la Constitución Económica o en el ámbito de la economía privada y pública.

\section{I- LA CONSTITUCIÓN ECONÓMICA}

Comienzo el análisis recordando que, entre 1974 y 1975, transcurrían en Chile debates en la Comisión de estudios de un proyecto de la nueva Constitución que presidía don Enrique Ortúzar, en la prensa y en otros lugares, de manera circunscrita, temerosa podríamos decir, porque el Gobierno Militar en esos tiempos era fuerte y duro, severo, pero había margen, espacio, debemos reconocerlo, para entregar elementos de juicio sobre el debate que se estaba llevando a cabo.

Yo tuve, a fines de año 1974 y en los primeros meses de 1975, la osadía de escribir unos artículos planteando la necesidad de que la Comisión Ortúzar, al estudiar y aprobar el anteproyecto de la Carta Fundamental, contemplara pocas pero claras y bien 
concebidas disposiciones de carácter económico. Sostuve que las Constituciones del presente y del futuro no podían ser ya concebidas como Cartas Fundamentales únicamente políticas, vale decir, restringidas o limitadas a lo que se llama el instrumento de Gobierno, como hemos dicho. Dije que, las grandes Constituciones, como la de Filadelfia de 1787, incluido el Bill of Rights, vale decir, con la Declaración de Derechos que se le agregó en 1791, o como era la Ley Fundamental o Básica de Bonn, de 1949, o la Constitución francesa de 1958, a raíz de ser aplicable el preámbulo de la Constitución de la Cuarta República de 1946, o en fin, como sucedía con la Constitución de diversos otros países, - la mejicana de 1917 y varias más-, el nuevo Código Político de Chile tenía que articular cláusulas dedicadas a establecer las bases y finalidades esenciales o fundamentales del régimen económico, privado y público.

Cuando yo planteé eso, creí que estaba proponiendo el debate de un tema que me parecía que no podría suscitar mayores dicusiones, porque era, en el fondo, salvar un vacío claro que tenía la Constitución de 1925. Esta última, Uds, recordarán que, en esta materia, salvo las disposiciones del Art. 10 № $10^{\circ}$ sobre el derecho de propiedad y una que otra dispersa en los números restantes de ese mismo, carecía de una definición, en términos precisos, claros y consensuados sobre el régimen económico.

Lo resumido derivó en que, la Constitución de 1925, fue una Constitución neutra, aséptica, carente de definiciones en el punto referido. $Y$ cuando tenía puntualizaciones más o menos nítidas eran inconvenientes, porque resultaban contrarias al ejercicio de la iniciativa empresarial privada en materia económica, como era, por ejemplo, esa disposición que se le agregó en 1967, por virtud de la cual se decía que la indemnización por la expropiación de predios rústicos se podía pagar hasta en 30 años plazo, con los bonos o intereses que determinara la ley, de manera de que no había garantía de que se recuperara el poder adquisitivo que significaba la pérdida del bien expropiado. Por último, el legislador era soberano y, sin ulterior recurso, para determinar la indemnización ponderando los intereses de la comunidad y de los expropiados.

Pues bien, ocurrió que mis ideas suscitaron polémica. Quedé sorprendido de que se produjera ese efecto. Fui acusado de ser una persona que estaba planteando incorporar a la Constitución disposiciones largas, extensas, complejas; que eso iba a significar la redacción de un texto extraordinariamente amplio y difícil de llevar a la práctica; que lo que yo proponía era reglamentar en la Constitución lo que era el sistema económico y otra serie de afirmaciones de semejante naturaleza.

Consideré todas esas argumentaciones equivocadas, me parecieron injustas, infundadas y sobre todo, equivocadas y carentes de visión. Entonces seguí escribiendo, en el sentido que me parecía que notaba en Chile ignorancia de la doctrina constitucional contemporánea, lo cual no era disculpable en profesores que enseñaban la materia. Añadi que me parecía equivocado, porque el desarrollo de las sociedades, la evolución de ellas, indicaba que las Constituciones no podian circunscribirse solamente al Instrumento de Gobierno, sino que los ciudadanos en su vida diaria aspiraban a un régimen de vida que fuera satisfactorio en todo lo que es el aspecto social y económico: vivienda, trabajo, remuneración, educación, descanso, seguridad social, etc. Todos los dere- 
chos, como sabemos, de la segunda generación. En la Constitución, dije, tenía que haber una definición breve y clara, en esta materia. La Constitución no podía ser como había ocurrido con la Carta Fundamental anterior, neutra y susceptible de interpretarse de la manera más increíble, como Uds. recordarán.

Finalmente, debo decir que en la Constitución quedaron disposiciones sobre la libertad en la economía. Debo agregar que esas disposiciones se hallan en el Art. 19, principalmente en los $\mathrm{N}^{\circ} \mathrm{s}$. $20^{\circ}$, en materia tributaria; $21^{\circ}$ respecto a la libre iniciativa en el campo empresarial; $22^{\circ}$ sobre la igualdad de trato económico; $23^{\circ}$ acerca de la libertad para adquirir el dominio de toda clase de bienes; $24 \%$ referente al derecho de propiedad; $25^{\circ}$ relativo a la propiedad intelectual industrial; y $26^{\circ}$ o derecho a la certeza y seguridad jurídica, o sea, que todos esos derechos van a ser respetados por el legislador. Tales principios quedaron articulados en la Constitución y bien redactados, bien concebidos y bien plasmados, correctamente normados en lo que se llama el Orden Público Económico o lo que también se denomina la Constitución Económica de Chile.

Me parece que, esos principios y normas han sido tan exitosos que, desde luego, les puedo decir que han sido copiados. En la Constitución argentina de 1994 hay disposiciones casi literalmente tomadas de aquellas normas de la Carta Fundamental chilena de 1980. En la Constitución de Chequia o República Checa ocurre lo mismo; en la Constitución polaca, igual cosa; en la Constitución peruana de 1994 también; en la Constitución colombiana de 1992, análogo suceso.

O sea, han sido imitados dichos principios. Uds. tendrían, entonces, que preguntarse ¿por qué?

Respondo: Porque no fueron malos y eran necesarios. Segundo, pues estos principios han sido implementados de tal manera de que han permitido, sortear crisis graves del sistema económico chileno, me refiero a las de los 1982, 83 y 84 cuyas secuelas todavía está pagando el régimen democrático, y después superar la crisis que estamos viviendo, con los índices de cesantía que tenemos, el empobrecimiento de la población, la contracción de la producción, la caída de la inversión extranjera, etc. Recuerden que, de 1984 a 1998, Chile tuvo los índices de crecimiento económico más grandes del mundo, ya que solamente Singapur y me parece que hay otro país en el Sud Este asiático, podría ser Hong Kong o Tailandia, tienen índices de crecimiento económico comparables a los de Chile en esos años. El promedio del crecimiento anual de Chile en esos quince años fue del 7,8 y hasta $9 \%$ del PGB. Eso es algo sin precedentes y de sumo éxito.

Se dice que si Chile logra recuperar esos guarismos de crecimiento económico y los mantiene por otros 10 ó 15 años, se convertirá en un país desarrollado. Ojalá que así sea.

Sintetizo estos antecedentes porque dejan de relieve lo importante que es contar con una Constitución Económica, vale decir con una serie de principios y normas articulados en el código político que reconozcan, que aseguren la libertad en materia económica incluyendo las acciones y recursos judiciales destinados a tutelarlos. 
La Constitución, en otras palabras, resulta que ahora cuenta, es importante, juega el papel de una variable independiente $y$, muy relevante para el despliegue de la iniciativa privada con éxito en el desarrollo social y económico del país.

Creo, avanzando en este orden de ideas, que la Constitución Económica está íntimamente relacionada con la Constitución Política y con su homónima social; así como la Constitución cultural. Por cierto, esas cuatro Carta Fundamentales quedan sistematizados en la Constitución Jurídica. Son tan estrechos y esenciales aquellos ligámenes que, nos parece, es imposible separarlos o eliminarlos. Sólo para fines analíticos podemos, por lo tanto, seguir adelante refiriéndonos de manera específica a algunos tópicos del orden público, constitucional-económico.

Ahora bien, junto con afirmar, como he dicho, que esas disposiciones del Art. $19, N^{\circ} 20^{\circ}$ a $26^{\circ}$; especialmente, son la médula en el asunto, agreguemos que igualmente hay otras dispersas y que son igualmente acertadas.

Recuerdo las palabras de Ralph Darendorf, un sociólogo y cientista político alemán, actualmente Director del London School of Economics and Political Sciences, de Londres, cuando escribió que la economía social de mercado tiene que atravesar por un período, que es la primera etapa de su implementación, en que es menester realizar lo que el llama una acumulación de capital, para que, en una segunda etapa, fruto de ese ahorro, de tal esfuerzo de trabajadores y empresarios, se note una distribución del ingreso que sea equitativa. Agrega Darendorf que, si no se produce el paso desde la etapa de la acumulación del capital, que es dura y de privaciones, sobre todo para el trabajador y la trabajadora, a la segunda etapa, que es de la economía social de mercado, con énfasis en el aspecto social y que se manifiesta en mejoramiento de las condiciones de trabajo, sueldos y salarios, relaciones laborales, negociación colectiva, sindicalización, acceso al bienestar en la vivienda, la salud e higiene, el descanso, la seguridad social, en la educación, etc., entonces se va produciendo la pérdida de legitimidad del sistema. Esto, que con acierto lo observa Darandorf, es delicado y grave.

Los alemanes occidentales, cuarenta años atrás, tuvieron el cuidado de percatarse del punto y, por lo tanto, desde el comienzo, desde las primeras etapas de implementación de la economía social de mercado, siguiendo el pensamiento de Ludwig Erhard, del canciller Adenauer y de varios juristas y economistas importantes, como Ernest Forsthoff, trataron de lograr que se produjera este efecto: 4,5 , o hasta 8 años de acumulación de capital, de ahorro forzoso, de "apretarse el cinturón", podríamos decir, de empresarios y trabajadores, para dar paso después al bienestar, en términos paulatinos pero de avance constante, de una distribución del ingreso que fuera, si no perfecta, por lo menos equitativa, de modo que abriera las posibilidades de un mejoramiento de las condiciones de vida, espirituales y materiales, de toda la población.

No soy economista, queridos amigos. Tengo, empero, los elementos suficientes para interiorizarme de los problemas económicos en relación con los asuntos constitucionales. En consecuencia, no voy a emitir un juicio de autoridad sobre la situación económica o las perspectivas económicas de Chile, pero de lo que no me cabe duda, es 
que, en el primer aspecto del ciclo descrito, percibo una falla de la libertad en la Constitución chilena en materia económica.

Parece que nos hemos quedado en la primera fase del ciclo que señalaba Darendorf, en la etapa de acumulación de capital, con extraordinario esfuerzo primero de empresarios y trabajadores, pero últimamente de trabajadores. Por eso, la redistribución del ingreso, o sea, la entrada en la segunda etapa y su despliegue se nota que va avanzando lentamente y que, en muchos casos, incluso, no ha tenido verdaderos efectos positivos.

Se manifiesta, en realidad, en diversas publicaciones técnicas que la curva de distribución del ingreso en Chile es una de las peores de América Latina.

No quiero dejar la imagen de una reflexión pesimista, pero tampoco es sano callar que en nuestro país, sin hiel ni amargura, pero sí llamando la atención, la distribución del ingreso tiene que mejorar. Me parece que en esto existe una cuestión ética comprometida, no sólo jurídica, económica, hay un dilema moral. Si se quiere la estabilidad institucional de nuestro país, tienen que, sobre todos los economistas, saldar o hallar fórmulas para pagar la deuda que tiene Chile, con vastos sectores de ingresos medios y bajos. Es necesario entregarle a los gobiernos fórmulas que, sin destruir el mercado, manteniendo la prioridad de la iniciativa del sector privado de la economía, produzcan acceso al bienestar por todos los trabajadores y empresarios del país, y no únicamente por los segundos. Eso es urgente e indispensable para que en Chile exista un clima de convivencia social, política y económica sano, sin odios ni envidias, sin rencores, con delincuencia en retirada, sin esa añoranza de volver al Estado Benefactor o Providente que, todavía algunos conciben como el único capaz de hacer justicia distribuyendo bienes sin sacrificios.

He aquí un primer problema de la economía en la Constitución, de la libertad económica en la Constitución. Tengo la impresión que hay sectores y actores, que no están comprometidos con ese sentido de la solidaridad y de la distribución equitativa del ingreso nacional, indispensable para que todos participen del bien común.

\section{II- MERCADO LEGALMENTE REGULADO}

Hay otro aspecto jurídicamente pertinente de examinar, con ribetes técnicos más complejos, pero que no es posible dejarlo de lado.

El punto que voy a exponer, que ya está levantando inquietudes, va a adquirir connotaciones graves en los próximos meses y años. Me refiero al hecho de que la libertad económica en la Carta Fundamental o la Constitución Económica, se funda, claramente en la preponderancia o primacía del mercado, pero regulado, y esto únicamente mediante la ley.

Tal regulación del mercado, exclusivamente efectuada por la ley es lo que se llama la "reserva legal fuerte". Significa una garantía, certeza o seguridad para los agentes económicos, en el sentido de que no se volverá a la discrecionalidad adminis- 
trativa a través del ejercicio de la potestad reglamentaria, o de las resoluciones de organismos públicos de control como las Superintendencia o de organismos como los de control y defensa del consumidor, que dicta resoluciones, repito, actos administrativos que son de carácter discrecional y, por virtud de los cuales, se fue creando la estatización dentro de la economía chilena, terminando con un socialismo de Estado ineficiente, uno de los factores que llevaron a la intervención militar de septiembre de 1973.

Hay, por lo tanto, en la Constitución Económica de Chile una garantía que el Poder Constituyente le dio a los empresarios, a los agente económicos, a todos los que están dispuestos a invertir y a comprometer su patrimonio para el desarrollo del producto y bienestar nacional en Chile a través de la iniciativa privada. Esa confianza está en que, junto con los derechos que integran el Orden Público Económico, el único vehículo jurídico idóneo para regular su ejercicio imponiendo cargas, aumentando los gravámenes, limitando el disfrute de los derechos, estableciendo ciertas obligaciones, en fin, pero todo y exclusivamente mediante la ley. Se parte de la base de que la ley se discute en el Parlamento, que es un foro de transparencia, en que están representados los más diversos sectores de la Sociedad incluidos los de la economía, que el procedimiento nomonogenético de la ley, los trámites que llevan a la formación de la ella garantizan que hay debate, que se intercambian puntos de vista, y que el producto, resulta, por lo tanto, justo, aceptable o legítimo para todos.

En la democracia esa es la idea que sustenta- recuerden las palabras de Manuel García Pelayo- la legitimidad de la ley. Es la seguridad de la ley, mayor seguridad que la de un decreto del Presidente de la República o una resolución administrativa. Sobre esa base puede efectuarse inversiones, retiros o traslados de capitales, etc.

El problema está, fundamentalmente, en lo que dice el Art. $19^{\circ} № 21^{\circ}$ inciso primero de la Constitución, cuando asegura a todas las personas el derecho a desarroIlar cualquier actividad económica que no sea contraria a la moral, al orden público o a la seguridad nacional, respetando las normas legales que la regulen. Observen bien: Respetando las normas legales que la regulen... Estas cinco o seis palabras, "respetando las normas legales que la regulen" han dado lugar a 20 ó 30 requerimientos al Tribunal Constitucional; han motivado por los menos unos 500 recursos de protección en casi veinte años y varios recursos de inaplicabilidad. Es un tema cuya solución se halla pendiente.

¿Cuál es el sentido que, dentro de la Constitución económica, y en ese contexto de seguridad o certeza que brinda la reserva legal fuerte, tienen estas palabras del Poder Constituyente: "respetando las normas legales que la regulen" a la actividad empresarial privada?

Sin entrar a pormenorizar otras notas que merece el asunto, en el que profesionalmente me ha correspondido actuar ante el Tribunal Constitucional y antes los Tribunales Superiores de Justicia, resumo mi posición diciendo que la reserva legal no se puede entender en términos absolutos. No puede la ley, en efecto, entrar a regular hasta el último detalle del ejercicio de la libertad económica. Sería absurdo. Imagínense la 
extensión, minuciocidad y detallismo al cual tendría que entrar la ley para regular hasta la minucia, lo adjetivo, lo accesorio del ejercicio de la libertad económica en matería tributaria, materia arancelaria, de derecho a propiedad, expropiación, etc.

Quiero decir que es inevitable, aún más, es saludable que, de alguna manera y con injerencia acotada, la acción de la potestad reglamentaria del Presidente de la República, aunque sea con el carácter de norma destinada a complementar lo que está o se haya con antelación establecido en la ley.

Esta es la fórmula que a mí me parece que se tiene que aceptar en definitiva. Vale decir, una fórmula que podríamos Ilamar flexible. El legislador tiene siempre que legislar lo que es el núcleo central de la libertad económica. Tiene que dejar suficicicntemente asegurados y no en la incertidumbre, los derechos de carácter económico que hemos mencionado. El legislador no puede ser flojo, indolente ni cómodo. Debe ser responsable y serio al acometer su función normativa. Pero tiene बue ser consciente también que no le corresponde descender al campo de la ejecución pormenorizada de la ley, el cual, según el principio de separación de órganos y funciones dentro del Estado democrático, es el ámbito propio de la potestad reglamentaria. Si en la potestad reglamentaria el Jefe del Estado se excede, se sobrepasa o desvfa, existen dentro del sistema jurídico chileno, garantías, recursos, acciones procesales y de otro carácter, como la toma de razón por la Contraloría General de la República, que aseguran, sobre todo a través del recurso de protección ante la Magistratura Superior, que no se tolerará que el Jefe del Estado, o quien sea, atropelle el Derecho fundameniáli por la vía de la discrecionalidad arbitrariamente ejercida.

Esa es otra tensión: Ley o reglamento dentro de la libertad económica en la Constitución es importante captar el asunto, porque veo que, sobre todo en la Cancer= tación, hay sectores que quieren más potestad reglamentaria, cada vez más regulación por esa vía, como quien dice que el Jefe de Estado tenga más y más facultades para regular el ejercicio de los derechos de carácter económico. En la Oposición sẹ piensa en términos diametralmente divergentes, menos potestad reglamentaria, para que ojalá desaparezca de manera que, toda la materia, aunque sea hasta el último detalle, quede establecido en la ley.

Son dos posturas que revelan una situación difícil de conciliar, salvo que lleguemos, como lo voy a decir luego, a algún grado de consenso en la irreformabilidad de ciertos parámetros constitucionales que se han demostrado esenciales.

Me parece, por último, que la libertad económica ha sido clave en el proceso de desarrollo económico de Chile y que se ha traducido, además, en un proceso de desarrollo humano, vale decir, espiritual y material, importante de la población de nuestro país.

Soy un convencido que sin desarrollo económico es difícil el desarrollo social y político. Tienen que ser concomitantes y no una después de otro, excluyéndose o cancelándose. Empero, creo que sin uno no se puede tampoco, por las relaciones, nexos o 
ligámenes que existen en diversos aspectos, visualizar un desarrollo pleno del país en lo que el PNUD llama desarrollo humano.

La importancia que tiene la Constitución para la libertad económica centrada en el mercado regulado, vale decir, en la política económica social de mercado, con Estado subsidiario y agentes económicos privados en calidad de actores prioritarios. Ese rasgo decisivo explica por qué se reconoce a estas materias el máximo de rigidez constitucional. Quiero decir que las seis materias que mencioné del Orden Público Económico, se encuentran protegidas con la exigencia de un quórum de dos tercios de los Diputados y Senadores en ejercicio para ser reformadas en la materia. Esta es una demostración de seguridad o certeza jurídica, aunque sea únicamente a nivel del texto positivo y, ojalá, que se extienda al plano de la cultura.

\section{III- CONSTITUCIÓN Y CULTURA}

Quiero referirme en los minutos que faltan al cuarto aspecto o dimensión de las libertad que me corresponde examinar, tras lo cual, como dije, les entregaré las conclusiones o reflexiones finales. Después me pongo a disposición de la audiencia para contestar las preguntas u observaciones que tengan a bien formular.

La Constitución Cultural de Chile o la libertad en materia cultural en la Constitución nos lleva a plantearnos, en primer lugar, una reflexión, según la cual es indispensable decir qué entendemos por cultura y, por lo tanto, qué es la libertad en materia cultural y la Constitución cultural desde el punto de vista de esa libertad.

Creo que la cultura es susceptible de numerosas definiciones, no todas coincidentes sino al contrario. Pero después de leer muchas, de pensar en ellas, de reflexionar cual me parece la más aceptable o acertada, concluyo que no hay nada más claro que la gran reflexión del insigne pensador mexicano Octavio Paz (Q.E.P.D.). El decía que la cultura abarca ese conjunto complejo de modos o maneras de ser y de obrar, de sentir y anhelar más o menos generalizados o difundidos dentro de una comunidad con una identidad propia. Un modo de ser y de obrar, de sentir, de pensar, de proyectar y anhelar más o menos generalizado dentro de una comunidad sea una Nación, una etnia que posee autoidentificación y que la hace distinguible o diferenciable de otras.

Como consecuencia de esta visión, el autor citado piensa que es posible pensar que la cultura se traduce o se expresa en una capacidad de obrar sobre la naturaleza y sobre el prójimo. Sobre la naturaleza, por ejemplo, se construye, a veces se la respeta, en otras se la depreda; y sobre el prójimo, la cultura se manifiesta con la educación, la enseñanza, la ciencia y la tecnología. La cultura abarca, por lo tanto, todos esos aspectos. De eso deseo decir algunas palabras en relación con la libertad.

Pienso que nos debemos referir, en primer lugar, a la libertad cultural en relación con las fases primarias o fundamentales del proceso cultural, es decir, la educación y la enseñanza. 
En lá illateria encontramos el Art. 19 № $10^{\circ}$ y $11^{\circ}$, dos disposiciones en general bastante bien concebidas y que son de trascendencia. Digo en general bien concebidas, porque también adolecen de errores. Si Uds. examinan el Art. $19 № 10 \%$, se saltan el inciso primero, avarican al segundo, llegan al tercero y caen en el cuarto, se detienen en este última, en el quinto y en el sexto y constatarán qué nada tienen que ver con la educación. La educación, queridos amigos y amigas, es el proceso por virtud del cual el educador infunde valores al educado o educando, valores como el sentido del respeto y sacrificio, la devoción y el trabajo, el esfuerzo y el tesón, la honestidad y la transparencia, el diálogo y la tolerancia, la sinceridad y el coraje. Eso es educar. Es infundir valores en el educando.

Nada tiene que ver, o muy remotamente y tan solo de manera indirecta, con la educación lo que se manifiesta en esos incisos finales del Art. 19 № 10, cuando se dice, por ejemplo, que la enseñanza gratuita es obligatoria. ¡La educación no es enseñanza! ¡Educar no es enseñar! Idéntica observación vale a propósito del Estado, el cual tendrá que contemplar los recursos necesarios para proporcionar gratuitamente la enseñanza básica a quien no tenga los recursos para procurársela por si mismo. Se confunden, en suma, ambos conceptos.

A renglón seguido, el Poder Constituyente entró en el Art. 19 № 11, este se refiere a la libertad de enseñanza. Ahí quedó mal redactado, deficientemente hilado el precepto, porque si Uds. lo leen comprobarán que la Constitución asegura a todas las personas: № 11. - "La libertad de enseñanza incluye..,"

Debió decir: "La Constititueién asegura a todas las personas: La libertad de enseñanza. Esta incluye el derecho a abrir, establecer, operar...", en fin, toda clase de entidadeş de educación y lo que viene después. Pues bien, la libertad de enseñanza, a diferencia del derecho a la educación, es un proceso metódico de transmisión de información al estudiante; es una sucesión ùe actuaciones, realizadas planificadamente, que busca la trancmirión y evaluación, de información por el pedagogo al estudiante. La libertad de enseñanza, por lo tanto, no tiene como rasgo definitorio y característico el esfuerzo por infundir valores al educando, por formarlo. El verbo rector que caracteriza el derecho de la educación es formar la personalidad del educando. En cambio, en la libertad de enseñanza el verbo rector es informar transmitiendo antecedentes, elementos de juicio, datos y cifras, etc. al educando.

Educar y enseñar, obviamente, se complementan. Son procesos que deben ir juntos. Pero no creo que sea difícil para Uds. captar que es mucho más complicado y relevante educar que enseñar. Lo que yo anhelo en las clases, por ejemplo, y estoy seguro que con el esfuerzo de Luz María y de los Profesores aquí presentes se hace todo lo que está al alcance de ellos por cumplir este objetivo, es que el profesor eduque y no solamente que enseñe. Que el Profesor no transmita sólo información sobre el Derecho. que eso es enseñar, sino que eduque en el Derecho al estudiante, infundiéndole, por ejemplo, valores como la importancia que el respeto del Derecho tiene para la paz social, para la concordia, para la solución justa y equitativa de los problemas sociales, para que se renuncie a la violencia, se comprometa el joven o el adulto con los caminos 
del Derecho, que no son los caminos de la fuerza ni la violencia sino del diálogo y la persuasión, la razón y la coherencia de fines y medios. Eso es educar.

Lo que yo esperaría es que el estudiante haga suya la actitud de ser educado y no solamente de ser enseñado. Siempre les digo a mis alumnos cuando trato estas garantías, cuantas veces en la vida me he encontrado con personas, chilenos o extranjeros, de todas las edades y condiciones sociales, que son bien enseñados, en el sentido que tienen post grado, título profesional, destreza en el campo de ejercicio de su actividad o industria, ipero que son mal educados! Son personas descorteses, intolerantes, prepotentes, mentirosos, arrogantes, atropelladores.

No siempre, entonces, van las dos áreas juntas. El ideal sería que nuestra cultura tuviera esta dualidad de valores equilibrados: Seamos chilenos o chilenas no solamente enseñados o instruidos sino que educados; sepamos comportarnos con respeto recíproco, tolerancia, sobre todo en los días que vivimos y que vendrán. Pienso, a veces, que la reconciliación podría tener mucha incidencia con el proceso educativo, sobre todo de la juventud.

\section{IV- CONCIENCIA Y LIBERTAD}

En este orden de ideas tendríamos que mencionar ciertas disposiciones constitucionales de trascendencia, como es la libertad de conciencia, la manifestación de todas las creencias y el ejercicio libre de todos los cultos.

Esta es una materia que no creo que les resulte problemático captar por su importancia en la cultura de Chile. Todo lo que dice relación con la libertad de conciencia, la libertad de cultos, la manifestación de las creencias, efectivamente, evidencia el proceso cultural de un país.

Deseo formular aquí un par de comentarios.

Primero, llamarles la atención que la disposición que estoy comentando se halla presente en el Art. 19 № 6 de la Carta Fundamental. Esa disposición, queridos alumnos y alumnas, tiene importancia singular. $Y$ si algo les puedo dejar como lección de hermenéutica constitucional o interpretación constitucional, es que se detengan a pensar y, ojalá que de aquí resulte algún interesado en hacer una memoria de licenciado, en ¿qué quiere decir la expresión "libertad de conciencia" ?

Se enseña tradicionalmente, y podríamos decir que es correcto hacerlo pero incompleto, que todos los elementos que voy mencionando, se refieren a la libertad de culto. Pero el precepto se refiere a mucho más que eso. Creo que en los tiempos que vivimos, la libertad en la cultura y la Constitución Cultural de Chile tienen en esta nor$\mathrm{ma}$, en la libertad de conciencia, conciencia en el sentido tanto sicológico o de facultad intelectual de aprehender, cuanto conciencia en el sentido de conciencia moral, voz de la conciencia, llamado de la conciencia, uno de los pilares fundamentales. 
Pienso que es a propósito de la libertad de conciencia que Uds, tienen que plantearse en Filosofía o Teoría del Derecho, o en cursos de Derecho Tributario o Derecho Penal, o en nuestra cátedra de Derecho Constitucional, cuestiones tan candentes y difíciles como es, por ejemplo, ¿porqué debo yo obedecer o no obedecer al Derecho, si tengo libertad de conciencia? ¿porqué debo obedecer la que considero es una ley justa o desobedecer lo que reputo una ley injusta?

Hace pocos días ocurrió la siguiente situación concreta.

En la Corte de Apelaciones de Valdivia un abogado fue conminado por un Juez de ese territorio jurisdiccional a asumir la defensa de un traficante de drogas. Aquel abogado, apelando a esta cláusula, la libertad de conciencia, dijo: "Yo no puedo ser obligado a defender a quien reputo que es un individuo que ha atentado en contra de los que yo considero los más sagrados principios de la convivencia. No puedo defender a un traficante de drogas". Sepan Uds., porque la prensa ha hecho caudal de este caso, que el rechazo del abogado fue, en definitiva, desestimado por la Corte de Apelaciones de Valdivia, la cual obligó al abogado, bajo sanción de aplicarle medidas disciplinarias, a asumir la defensa como profesional de ese traficante. Sin embargo, el abogado recurrió de protección. El asunto se halla pendiente en la Corte Suprema. Creo que el abogado tiene la razón y que los Tribunales, hasta aquí, se han equivocado. Pero reconozco que la libertad de conciencia sicológica y moral puede ser usada también abusivamente.

Es a propósito de la libertad de conciencia, como un elemento cultural por ejemplo, que se plantea la duda respecto al Servicio Militar Obligatorio. ¿Hasta qué punto un joven puede excepcionarse en Chile de ser obligado a cumplir el Servicio Militar Obligatorio, invocando, como ha ocurrido en otros países la libertad de conciencia?. Me quedo pensando, ¿hasta qué punto el problema de Londres o el de los derechos humanos en Chile, más que un dilema jurídico, más que una encrucijada política, es un problema de conciencia o ético y que, por eso mismo, resulta tan difícil de resolver?

No sé. Quisiera decirles que este № 60 del art. $19 \%$ no se refiere solamente a la libertad religiosa. Creo que antes de la expresión del culto, vale decir de la reverencia a Dios y a los bienaventurados, o de la expresión de la fe, uno tiene que gozar de la libertad de conciencia.

No hay nada más cercano a la dignidad de la persona humana que la libertad de conciencia moral y sicológica. Desde ahí comienza a desarrollarse una cultura, en el individuo y la sociedad.

El otro comentario que deseo hacer se refiere a que me parece lamentable que haya sido aprobado un texto legal, que leí ayer no será vetado por el Presidente de la República y, por lo tanto, está destinado a convertirse en ley la próxima semana. Ese texto regula el ejercicio de la libertad de cultos en Chile. Estimo que esa ley era innecesaria. Pienso, además, que es un estatuto deficiente. Agrego que lo estimo inconstitucional y, en fin, no callo que, lamentablemente, puede generar dificultades prácticas. 
Uds. saben que, entre otras afirmaciones, esa ley establece una igualdad entre todas las confesiones religiosas. Me parece que eso es discutible.

Soy católico, apostólico romano, pero no puedo, en virtud de esos principios, exigirle a un evangélico que actúe según mis postulados. Tengo el mayor respeto por los evangélicos, por los masones, los anglicanos, los musulmanes, etc., pero otra cosa distinta es desconocer los 460 años que tiene la Iglesia Católica de impronta valiosísima en la cultura de Chile. Desde tal punto de vista no se pueden igualar las instituciones. Se viola el principio de isonomía o de igualdad ante la ley no solamente cuando se desiguala debiendo igualarse, sino que cuando se iguala debiendo desigualarse. Ese doble aspecto de la igualdad ante la ley se vulnera en este estatuto. Entonces y por ejemplo, en virtud de esta igualación debiendo desigualarse, es posible que mañana se diga que no debe existir un Vicario General Castrense sino que tantos dignatarios de esa naturaleza como confesiones religiosas se hallen acreditadas en los Comandos Institucionales. Puede darse el absurdo que tengamos varios generales que sean Vicarios Generales Castrense, o que en un mismo hospital existan diversas capillas o templos. O que instituciones tan importantes como una orden religiosa de la Iglesia Católica pueda ser disuelta por un Juez de Letras, en virtud de un requerimiento del Consejo de Defensa del Estado. Son situaciones absurdas y que llevan a pensar por qué se hizo esto. Queda la impresión que por votos y eso no es buena razón para legislar.

\section{V- LIBERTAD DE EXPRESIÓN Y CENSURA}

Terminaré diciendo que me parece que, en relación con la cultura, también está el proyecto de Reforma Constitucional que envió el Presidente Frei Ruiz - Tagle para modificar el Art. $19^{\circ}$ № $12^{\circ}$ inciso final de la Constitución, que se refiere a la existencia de un sistema de censura de la producción cinematográfica y de su publicidad.

Hoy, Uds. pueden leer allí que dice lo que acabo de recordar: Existirá un sistema legal de censura de la producción cinematográfica y de su publicidad. Se usa la palabra censura. El Presidente Frei Ruiz-Tagle envió al Congreso un proyecto disponiendo que existirá un sistema de calificación, pero no de censura, y que la ley, además, establecerá los mecanismos para el desarrollo de las actividades artísticas. Fomentará, financiará, la realización de actividades artísticas. Esta modificación constitucional diría que tiene aspectos positivos y otros que, por lo menos en este momento, suscitan incógnitas o dudas.

Me parece, en efecto, que es indiscutible, como ya lo dije a propósito de la pregunta de un asistente, que si creemos en la libertad responsablemente ejercida, no podemos estar a favor de la censura. Yo soy claramente contrario a la censura.

Pero, como ya lo dije también, creo que la censura hay que definirla, pues de lo contrario deviene cualquier cosa y por lo tanto no es nada o es todo.

Para mí la censura es cualquier impedimento ilegítimo al ejercicio de la libertad de expresión, sea en el campo de la educación o de la enseñanza, en el ámbito de los 
medios de comunicación social, que no es el único campo, el de la comunicación social a través de diarios, revistas, periódicos, libros. Es también cualquier impedimento que se pueda ejercer en materia de pluralismo político, de partidos, o en las actividades de la libertad de cátedra o de la libertad científica y tecnológica. Pero la expresión es impedimento ilegítimo, lo que pone de relieve que no todo impedimento tiene esas características y que, por lo tanto, hay impedimentos para el ejercicio de la libertad de expresión que no son censura, pues resultan ser perfectamente legítimos, justificados, proporcionados, razonables que existan. Es solamente el estorbo, injerencia o impedimento abusivo el improcedente e inaceptable. Eso es censura. Si por ejemplo, un periodista que trabaja en un diario, sea de esta región o de otra localidad del país, va en virtud de un recurso de protección a los Tribunales Superiores arguyendo que el editor o el director del diario le impidió publicar un artículo como él quería, o difundir una noticia de crónica como él pensaba que era correcto y que, por lo tanto, está siendo censurado ¿podemos decir que eso es censura previa? o, más bien, que está vigente un contrato de trabajo celebrado entre el medio de comunicación social, el diario, en el ejemplo que estoy proponiendo, y dicho profesional por virtud del cual el periodista ha aceptado, libremente ha consentido someterse a las normas en virtud de las cuales el director 0 editor responsable es el que tiene la última palabra respecto a lo que se difunde o no difunde a través del medio.

A mi no me cabe duda que es esta última situación la que se encuentra presente. No es un problema de censura.

Si el padre educa a un niño y le dice no hagas esto ¿lo está censurando? Si las organizaciones internacionales competentes dicen: "No se puede seguir clonando seres humanos, porque esto va a llevar a la destrucción de la especie". ¿están censurando a los científicos?, ¿o están velando por el bien común de la humanidad? Si el Ministro del Interior afirma a un periodista: "No le voy a entregar estos antecedentes", o el General de Carabineros Jefe de la Zona dice: Yo tampoco le voy a entregar a los periodistas tal - cual información, porque están comprometidos procedimientos policiales que serían graves que se conozcan por terceros" ¿está censurando a los medios? Creo que son innumerables, infinitas, incontables las situaciones en que Uds. podrían encontrarse con que se usa la palabra censura para presentarse de manera políticamente correcta, pero claramente con el objeto de abusar de la libertad de expresión. Entonces, uno tiene que estar consciente de que la mejor manera de destruir, estropear, perjudicar la libertad de expresión es abusándola. La censura no es cualquier impedimento. Hay innumerables situaciones, como he tratado de demostrarles, en que la cultura indica que lo razonable, sensato o correcto es reconocer que son conceptos distintos y que es improcedente asimilarlos a la censura.

\section{VI- EPÍLOGO}

En relación con este tema cultural, termino diciendo que enfrentamos problemas en las áreas referidas de la educación y de la enseñanza, de la conciencia y del culto, de la creación artística, científica y tecnológica, de la difusión de ideas y pensamientos. 
que son complicados y respecto de los cuales no podría silenciar, al ir cerrando ya estas reflexiones, mi posición personal.

Digo, en primer lugar, a propósito de la libertad de conciencia, a la cual realcé como la más importante de todas las materias que he mencionado dentro del área cultural, que el mayor de los problemas que enfrentamos es el relativismo moral.

En virtud de lo que se llama la postmodernidad, la filosofía de Derrida y de otros filósofos, especialmente franceses, lo que se llama el deconstructivismo, se sostiene la licencia o derecho para manifestarse dentro de lo que se denomina el pluralismo irrestricto. Cada cual tiene derecho, sea varón o mujer, sea o no homosexual, sea o no mayor o menor de edad, sea o no comunista, sea o no católico, sea o no así o asá, a manifestarse como quiere, en los términos más absolutos. Nadie tiene el derecho, de ninguna naturaleza, de decirle que hay pautas morales dentro de la Sociedad, que hay códigos objetivos de ética que tienen que ser respetados.

Entonces, resulta que este derecho a la manifestación en términos ilimitados lleva que se puedan manifestar, públicamente, en marchas y concentraciones, en documentos, en el cine o en cualquier medio de comunicación social, en los términos que se antojen, por lo cual sería censura sancionar los excesos que se pueden cometer.

Todo esto se ampara o fundamenta en términos de relativismo moral. Creo que uno de los cambios más profundos que se están experimentando en Chile y, en general en las sociedades jóvenes, es la sustitución de los códigos culturales en términos de su relativización, de la mayor subjetividad, en el sentido que no existen estándares objetivos heterónomos de carácter cultural, que esa voz o llamado de la conciencia, no existe y que cada cual es dueño de hacer lo que quiere, sin que nadie pueda impedírselo.

Les dejo planteada esa inquietud. Si esto es así, ¿en virtud de qué podemos decir que existe el Derecho, que el ordenamiento jurídico es susceptible de ser impuesto, si cada cual tiene la facultad de manifestarse como quiere?

Como Kant escribió ¿por qué tengo que yo obedecer, si soy igual que tú y, por ende, dueño de hacer lo que quiera?

El sistema jurídico, los patrones morales, los parámetros éticos según los cuales se desenvuelve la cultura en una sociedad, se comienzan a desmoronar. Ya nadie puede, en virtud de ningún principio objetivo, pedir o exigir una conducta determinada al prójimo. Todos somos amos de nosotros mismos y dueños de hacer lo que queramos.

Esa cuestión es de enormes consecuencias, porque los cambios valóricos son más importantes que los cambios en la Constitución Política, en la Constitución Económica, o en la Constitución Social. Estos cambios culturales, tales alteraciones valóricas con la idea de libertad irrestricta, incluso desenfrenada, necesariamente termina impactando en forma negativa en los otros aspectos de la libertad explicados esta tarde.

Eso mismo me lleva, en segundo lugar, a plantearles el problema de la ética política, social, económica, jurídica y de la cultura. 
Creo en la ética, queridos amigos. Creo en la ética en términos de un código moral objetivo. Creo que ese código moral objetivo es heterónomo. Creo que ese código moral objetivo lo ha grabado Dios en la conciencia del ser humano. Sin embargo, para creer en tal código moral objetivo no necesito ser creyente en Dios. Necesito creer por último en la inteligencia humana, en la manera racional del ser humano de desenvolverse y me basta eso, por último, como mínimo, como lo dice Nolberto Bobbio, para concluir que hay ciertos estándares, determinados patrones, normas de conducta moral ineludibles que tienen que ser aceptadas o reconocidas por todos, como objetivamente imperativas en una comunidad, si es que se quiere desenvolver nuestra convivencia con un mínimo de respeto, de racionalidad y de paz.

Me parece, sin embargo que, hay gente, incluso en Chile, que hoy se manifiesta en términos contrarios a lo expuesto. Entonces y por ejemplo, en virtud de ese relativismo, acompañado de la falta de criterios éticos, se habla de los derechos humanos y está muy bien que se hable y se haga la defensa de tales derechos. Lo aplaudo y lo aliento, no hay duda. Pero, simultáneamente, se plantea el aborto, el aborto masivo finañciado por el Estado, a cualquier mes o época de gestación de la criatura que ya es persona en el vientre materno. ¿Cómo puedo defender los derechos humanos si comienzo desconociendo o desprotegiendo el primero y más fundamental de esos derechos, que es el derecho a la vida? Lo mismo digo respecto a tantos otros fenómenos como es la eutanasia, en que apelando a la libertad de conciencia Uds. saben que se la intenta justificar, legalizándola en Australia y en Holanda. Somos testigos de la batalla que se está dando en EE.UU., país en el cual un fallo reciente rechazó tal pretensión, pero el Dr. Keworkian sigue adelante con sus procesos para difundir la muerte dulce.

Tantos otros fenómenos podríamos mencionar: la destrucción de la familia, por ejemplo. El informe del PNUD para Chile, de 1998, dice que deben otorgar atención al tema, pues aquí se está destruyendo el tejido básico de convivencia social que es la familia, en términos que ojalá no suceda como ya ha ocurrido en otros países.

Termino, queridos amigos.

Ya he dicho que, en el plano de la ciencia y de la tecnología, se percibe una serie de ataques a la vida y la dignidad de la persona humana. Me referí al caso de la clonación. Uno se queda pensando si acaso la ciencia y la tecnología se están desarrollando para el servicio del hombre o en contra de la persona humana. Hay cierta contradicción, con algo de cinismo. Se defienden los derechos humanos, pero simultáneamente se los desconoce de la manera que estoy mencionando: El aborto, el ataque a la dignidad de la persona, la destrucción de la familia, la perversión de costumbres, la pedofilia y cuantos otros fenómenos que en estos momentos son depredadores de una convivencia civilizada.

\section{CONCLUSIONES}

La libertad en la Constitución es una sola idea, son un solo gran valor y que, por lo tanto, creo que es inseparable en sus cuatro vertientes principales. 
Donde hay libertad tiene que existir una Constitución justa y donde impera una Constitución justa no cabe duda que va a reinar la libertad. Esta tarde he descrito tan sólo cuatro áreas o zonas de libertad en la Constitución. Las que hemos Ilamado la libertad y la Constitución Política, Social, Económica y Cultural.

Curiosamente no hemos hablado de la libertad y de la Constitución Jurídica. Entendámosla absorbida en el concepto de Constitución.

En general y como tercera conclusión, esas cuatro áreas se hallan adecuadamente articuladas, redactadas y plasmadas en la carta fundamental chilena vigente. Repito, no siento ningún temor al decir que esas áreas se hallan en general acertada o adecuadamente articuladas en la Carta Fundamental vigente y en su legislación complementaria.

Agrego: El éxito se debe, y el mérito del Poder Constituyente se halla, en que lo hizo sin sesgos ideológicos. Creo impropio, injusto, inexacto decir que esas disposiciones corresponden a una Constitución liberal por ejemplo, como se ha dicho a propósito del Orden Público Económico; o a una Constitución conservadora, como lo ha sido a propósito del orden social; o una Constitución autoritaria, como se ha manifestado con relación al orden político.

Me parece que esas son afirmaciones ideológicas y, por lo tanto, carecen de solidez conceptual objetiva.

Como cuarta conclusión, si se demandan, si se exigen reformas a la Constitución, -las que llamábamos en el debate reformas maduras-, son casi sin excepción dirigidas a lograr una Constitución Política que sea plenamente democrática. En eso yo estoy de acuerdo. Creo que las reformas que hay que introducir son a la Parte Orgánica, pero no a la Parte Dogmática del Código Político. Las apoyo y estoy de acuerdo con ellas. Ojalá sean consensualmente debatidas pronto y aprobadas sin tardanza.

Alli surge el dilema del académico y del demócrata, del hombre que quiere ser tolerante. Quisiera hacer un esfuerzo por ser académico, demócrata y tolerante, y por lo tanto, hacerme cargo de las dudas, problemas, objeciones y dificultades que plantean quienes se oponen a esa reforma. Los invito a Uds., queridos alumnos y alumnas, a situarse también en la posición de quienes se oponen a la reforma ¿por qué lo hacen?

Ya dije: Coincido en la necesidad de esas reformas políticas porque las estimo maduras, necesarias, inevitables y saludables. Sin embargo, si se hacen ellas, ¿creen Uds. que se desencadenará o no el cambio de la Constitución Social, el cambio de la Constitución Económica y el cambio de la Constitución Cultural que hemos descrito esta tarde? Es decir ¿el cambio de aquello que hemos defendido como acertadamente articulado?, ¿creen Uds. que en Chile hay sectores que nunca van a hacer eso o están esperando que se echen abajo los diques de la Constitución Política para, justamente, inducir y lograr tales cambios? Sobre la propiedad, por ejemplo; o sobre los tributos, la educación o la enseñanza ¿Se oponen, por lo tanto, muchos chilenos y chilenas a esas reformas, por miedo, por temor, a que suceda lo que yo no quiero que ocurra? 
Si eso es así, entonces ¿cómo lograr, como hacer que en Chile exista estabilidad de nuestra Constitución y que la libertad dentro de la Constitución también sea un bien por todos compartido, sin temores y sin coerciones? Repito ¿cómo lograr consolidar la Constitución?

Este es el gran problema institucional de Chile. Uds. están viendo en Brasil, en Colombia, en Venezuela, en Perú, en Ecuador, que es un problema grave de América Latina. Un problema que tiene ya casi 200 años, casi insoluble para nosotros.

¿Cómo lograr, en otras palabras institucionalizar la Constitución? Esto significa hacer que una Constitución se convierta en institución perdurable, arraigada en la cultura, estable, sólida, respetada, que pueda cumplir lo que expliqué de la Constitución que predica Herman Heller, o sea, la normalidad de la vida normada por el Derecho.

Para eso, para lograr institucionalizar, arraigar, convertir en perdurable una Constitución, sea la de 1980 o la que modifiquemos, nos falta cumplir no una sola condición. Nos faltan, en efecto, satisfacer muchas exigencias, pero quiero mencionar algo que me parece superlativamente importante. Nos falta, entre tales requisitos, una sola y compartida interpretación de nuestra historia y, como escriben Gabriel Salazar y Julio Pinto en su obra Historia Contemporánea de Chile, una sola y compartida imagen de Chile, un proyecto de país, esa visión singular del pretérito, del pasado de nuestra historia, que nos lleve a interpretarla, en función del presente, de manera que no seamos amigos y enemigos, unos víctimas y otros victimarios; y que culmine en un ideal de convivencia nacional ampliamente compartido.

Esa visión cohesionada, consensuada, al menos mayoritaria de lo que somos hoy día; esa visión, con las mismas características del presente y futuro, como la que Ernest Renan llamaba, en 1882, una Nación, una sola interpretación de los tres tiempos del verbo, que él la definía, entre otros rasgos, sobre todo como "un esfuerzo permanente por hacer sacrificios para vivir unidos", repito, un esfuerzo permanente por hacer sacrificios, todos, para vivir unidos, si no logramos eso, me parece muy difícil que podamos consolidar una Constitución y consolidar la libertad dentro ella.

Por lo tanto, mientras ese requisito no se cumpla, mientras no ocurra y se asiente ese fenómeno cultural, esa unidad tan noble y sincera que estoy demandando de los chilenos y que es asunto, a mi juicio, muy complejo, porque exige esfuerzo de generaciones, y por eso creo, siguiendo el consejo de Vladimir Rubilar, ojalá que te puedas referir a los jóvenes en este punto, aquí encuentro la ocasión de hacerlo. Mientras eso no ocurra, sobre todo en los jóvenes y en las jóvenes, este compromiso fundamental, definitivo, irrevocable, total, de entrega y nobleza propia de la juventud, con solidaridad y participación, en el sentido de luchar, con paz y tolerancia, por el éxito que nosotros los de mayor edad ya no tuvimos, en construir lo que el Cardenal Silva Henríquez llamaba "El Sueño de Chile", en un país que sea unido, justo, seguro, con libertad e igualdad para todos, nos parece muy difícil que podamos realizar, al menos en términos más o menos de corto o mediano plazo, el ideal que tanto reclamamos, sin ponernos antes de acuerdo en qué consiste y cómo forjarlo. 
Pero si Uds. me preguntan, al terminar, y con esto cierro mis palabras ¿qué hacer?, esa pregunta que tantas veces se hace con un cierto dejo de desesperación, ¿qué hacer, entonces?, sobre todo en este momento que me siento, bastante preocupado, ¿qué hacer?, ¿cómo avanzar hacia el horizonte descrito?

Les digo: No se me ocurre sino pensar en tres obras. Tratemos de ser transparentes, de educar y enseñar para la libertad. Hacer comprender a los chilenos y chilenas y a los extranjeros que en la Constitución debe quedar plasmada esa idea de la libertad ya vivida, y ese valor de la libertad que ya estamos viviendo, y que, sobre todo, además de ser honesto y transparente, ser educado en estos valores, de transmitirlos a través de la educación, de vivirlos podríamos decir sociológica y empíricamente, no en declaraciones insustanciales.

Si me preguntan ¿y cómo garantizar frente, a quienes se oponen a los cambios que considero tan necesarios, el éxito de la tarea? Respondo: No creo en los pactos constitucionales. Últimamente, algunos profesores de Derecho organizaron un seminario en Santiago dedicado al examen del Pacto Constitucional como garantía para quienes rechazan las reformas propugnadas.

Tengan presente que, el Pacto Constitucional de 1823 duró cinco meses. El Pacto de 1828 duró cuatro meses. El Pacto de 1833 no fue tal, porque la Constitución de ese año se hizo sin transacciones por los portalianos y pelucones que vencieron en Lircay. Tal vez, por eso mismo, el Código Político de 1833 duró más hasta que se dividió la aristocracia.

No creo, en resumen, en los pactos constitucionales. Creo, eso sí, que tiene que haber buena fe y voluntad generalizada, en términos de un compromiso adecuado con la libertad, con respeto de los derechos fundamentales. La experiencia, muchas veces dura, que ya hemos recogido como Pueblo, tiene que habernos hecho comprender y asimilar tales exigencias. Dentro de ese ámbito, créanme que no veo nada más seguro que aplicar todos los esfuerzos por asegurar que tengamos un Poder Judicial lo más independiente, lo más moderno, lo mejor capacitado y lo mejor remunerado que nos sea posible.

En ese nuevo Poder Judicial, en definitiva, descansa la libertad en la Constitución y ipara el cumplimiento de tal condición todos somos llamados y nadie puede dejar de aportar su contribución o talento!

¡Gracias, muchas gracias, por venir y escucharme! 